\title{
Microbial Metabolism and Incorporation by the Polychaete Capitella capitata of Aerobically and Anaerobically Decomposed Detritus*
}

\author{
Roger B. Hanson and Kenneth R. Tenore \\ Skidaway Institute of Oceanography, Post Office Box 13687, Savannah, Georgia 31406, USA
}

\begin{abstract}
Detritus derived from Spatind allerniflord (cordgrass), Gracilarid foliffera (red seaweed), and periphyton (mixed algae) was decomposed aerobically and anaerobically for various lengths of time and then fed to the polychaete Capitelld capitald in flow-through microcosms. Rates of detrital mineralization $\left(\mathrm{CO}_{2}\right.$ production), microbral respiration $\left(\mathrm{O}_{2}\right.$ consumption) and biomass (adenosine triphosphate and total adenylates, $A_{t}$ ), and net incorporation by $C$. capitata varied with detrital source and length of pre-aging. Oxygen consumption per unit microbial biomass ( $\mu$ moles $\mu \mathrm{gA}_{i}^{-1} \mathrm{~d}^{-1}$ ) increased linearly with age of the detritus: periphytic algal detritus had the highest daily increase of $4 \%$, followed by $G$. foliiferd and S. alterniflora detritus at $1 \%$ and $0.3 \%$ respectively. Metabolic respiratory quotient $\left(\mathrm{CO}_{2} / \mathrm{O}_{2}\right)$, which varied from $<1$ to about 50. 1, was a function of detrital source and age; it indicated that anaerobic bacteria were important decomposers of detritus. Net incorporation rates by $C$. capitata, microbial biomass, and $\mathrm{O}_{2}$ consumption rates did not differ among $G$. foliifera detritus aged under oxic and anoxic conditions. Rates of $\mathrm{CO}_{2}$ production, however, were up to 6 times higher for $G$. foliffera detritus aged anaerobically. The results suggest that anaerobic metabolism, which causes a high $\mathrm{CO}_{2}$ production, could represent a significant loss of carbon from benthic tood webs.
\end{abstract}

\section{INTRODUCTION}

Many factors regulate the decomposition and transformation of plant detritus. Microbial conversion, at least of more refractory detritus, is necessary before detritus is available as food for meiofauna and macrofauna (Fenchel, 1972; Tenore, 1976; Fenchel, 1978; Tenore and Rice, 1980). Following death of a plant, soluble organics leach from the detritus and are rapidly utilized by aerobic bacteria (Burkholder and Bornside, 1957; Gosselink and Kirby, 1974; Fallon and Pfaender, 1976). However, in salt marshes the bulk of vascular plant detritus is particulate and remains in low redox sediments for as long as a year (White et al., 1978; Hackney and de la Cruz, 1980; MacCubbin and Hodson, 1980), whereas seaweed and algae decompose within a few weeks to a month (Josselyn and Mathieson, 1980; Tenore and Hanson, 1980). The rate at which microbes decompose and detritivores utilize

\footnotetext{
- This research was supported by funds from the Oceanography Section, National Science Foundation (Grants OCE 78 25862 and OCE 77-19944). We acknowledge the technical assistance of Messrs. Bruce Dornseif and $\mathrm{H}$. Kenneth Lowery
}

particulate detritus depends on such factors as available caloric and nitrogen content, lignin and lignincellulose content, external nitrogen supply, particle size, and presence of oxygen and other terminal electron acceptors (Burkholder and Bornside, 1957; Gunnison and Alexander, 1975; Harrison and Mann, 1975; Haines and Hanson, 1979; Rich, 1979; MacCubbin and Hodson, 1980; Hanson, 1981; Tenore, 1981). Chemical inhibitors in the detritus may also influence decomposition rates and might depress consumption by macroconsumers (Valiela et al., 1979).

The marsh grass Spartina alterniflora has been regarded as a major food source for secondary consumers (Teal, 1962; Odum and de la Cruz, 1967). However, $S$, alterniflora detritus had the slowest decomposition rate and the highest conversion efficiency to microbial nitrogen among three marsh plants tested (Haines and Hanson, 1979). Thus, S. alterniflora detritus might be suitable as food for detritivores after it is converted to microbial biomass.

Incorporation of detritus by Capitella capitata and the rate at which detritus is oxidized and converted to microbial biomass in flow-through microcosms with 
periphyton, Gracilaria foliffera or Spartina alterniflora detritus were related to decay resistance and age of the detritus (Tenore and Hanson, 1980). However, total microcosm respiration and $\mathrm{CO}_{2}$ production rates were not reported because of possible differences in reduced end-products and mixed aerobic-anaerobic metabolism during aging of the different detrital types. Therefore, the influence of aerobic and anaerobic decomposition of detritus on the respiration and oxidation of the detritus was assessed by aging $G$. folifera detritus in continuous cultures under oxic and anoxic conditions. The results describe microbial metabolism during aging of these sources of detritus and incorporation of aerobically and anaerobically aged detritus by $G$. foliifera.

\section{MATERIALS AND METHODS}

\section{Detritus Aging for Microcosms}

Periphyton, Gracilaria foliifera and Spartina alterniflora were grown to produce homogeneously ${ }^{14} \mathrm{C}$ labeled detritus (Tenore and Hanson, 1980). Periphyton (an algal mat composed of diatoms, green and blue-green algae) and $G$. foliffera were cultured in illuminated tanks with seawater containing $\left[{ }^{14} \mathrm{C}\right] \mathrm{NaHCO}_{3}$. Labeled S. alterniflora detritus was prepared from plants grown for 3 months in an enclosed chamber with $\left[{ }^{14} \mathrm{C}\right] \mathrm{CO}_{2}$. Plant material was harvested, washed with seawater, rinsed quickly with $10 \% \mathrm{HCl}$ to remove surface-absorbed ${ }^{14} \mathrm{C}$, rinsed with fresh water, freeze-dried, and ground to pass through a 250 um mesh.

The different types of labeled detritus were aged at $20^{\circ} \mathrm{C}$ in 71 Plexiglas cylinders. The cylinders continuously received $91 \mathrm{~d}^{-1}$ of $0.45 \mu \mathrm{m}$ filtered seawater Inorganic nitrogen (145 umoles $\mathrm{NH}_{4} \mathrm{Cl} \mathrm{l}^{-1}$ ) was added to the water so that nitrogen would not limit decomposition. A circular Plexiglas plate moving vertically over the detritus ensured adequate water mixing above the detritus.

Detritus (including the microbial component) was removed from the cylinders at different times, freezedried, and kept frozen until used. We did not measure the microbial activity in these aging cultures. Because of this treatment before the detrital complex was introduced into microcosms, the activity in the microcosms was due to previous biochemical changes in the detritus-microbial complex.

Aged periphyton, Gracilaria folifera and Spartina alterniflora detritus was added to 1.51 microcosms $\left(0.018 \mathrm{~m}^{2}\right.$ surface area) with a layer of clean, fine sand ( $<0.3 \mathrm{~mm} ; 250 \mathrm{~cm}^{3}$ ) and $1.5 \mathrm{~g}$ dry wt. of labeled detritus. After Capitella capitata $(75$ worms micro- $\cos \mathrm{m}^{-1}$ ) were added, the microcosms were covered with airtight lids. Filtered (1 $\mu \mathrm{m})$ estuarine water, was pumped through the sealed microcosms at a rate of 351 $\mathrm{d}^{-1}$ to ensure an adequate supply of oxygen. The experiments were run in the dark at $20^{\circ} \mathrm{C}$ for $4 \mathrm{~d}$. The term 'microcosm' refers to the community consisting of the detritus-microbial complex and the polychaete $C$. capitata only.

Gracilaria foliifera detritus was aged aerobically (bubbled with air) and anaerobically (bubbled with $\mathrm{N}_{2}$ gas) in 18-1 flow-through chambers (Fig. 1). Detritus that washed out with the effluent was trapped in small

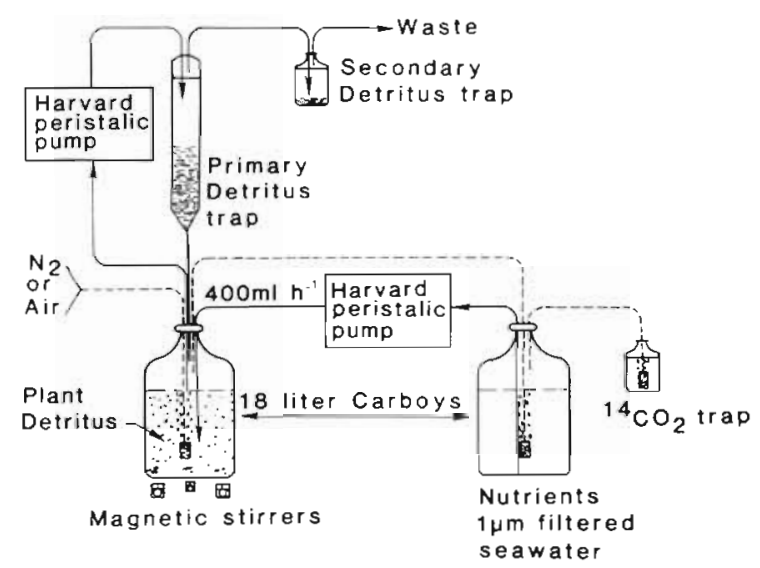

Fig. 1. Culturing system used to produce aerobically or anaerobically aged detritus

reservoirs and returned to the cultures daily. Sufficient inorganic nitrogen $\left(\mathrm{NH}_{4} \mathrm{NO}_{3}, 150 \mu\right.$ moles $\left.\mathrm{l}^{-1}\right)$ was added to the water, so that ammonium and nitrate would not limit decomposition and anaerobic metabolism respectively. This detritus was prepared as described above and then added to small 1.0-1 microcosms $\left(0.009 \mathrm{~m}^{2}\right)$ with $50 \mathrm{~cm}^{3}$ of sand and $0.75 \mathrm{~g}$ dry weight of labeled $G$. foliifera detritus. Capitella capitata (37 ind. microcosm ${ }^{-1}$ ) were added and the microcosms sealed. Seawater was pumped through these microcosms at a rate of $9 \mathrm{l} \mathrm{d}^{-1}$.

\section{Microbial and Macroconsumer Activity Measurements}

Metabolic activity of microbes and macroconsumers in the microcosms was estimated from the difference in carbon dioxide and oxygen concentrations in water entering and leaving the microcosm on Days 3 and 4 of the experiment (Hanson, 1981). Bubble-free water samples were collected in $50 \mathrm{~cm}^{3}$ syringes and injected into He-flushed serum bottles. Water samples were analyzed for $\mathrm{CO}_{2}, \mathrm{O}_{2}$ and $\mathrm{N}_{2}$ by stripping the gasses from the acidified water ( $\mathrm{pH}$ 2) into the helium-filled 
head space. Samples for gas analysis varied by less than $4 \%$ on a Carle Analytical Gas Chromatograph (columns: Molecular sieve $13 \mathrm{~A}$ and a mixed Porapak $\mathrm{N}$ $[60 \%]$ and $S[40 \%]$; temperature, $40{ }^{\circ} \mathrm{C}$ ) with a thermal conductivity detector, which was connected to a Laboratory Data Control dual input integrator From the volume of water passed through each microcosm daily, microcosm respiration $\left(\mathrm{O}_{2}\right)$ and detritus oxidation $\left(\mathrm{CO}_{2}\right)$ rates were calculated

Oxidation rates ( $\mathrm{mg}$ detritus dry $\mathrm{wt}^{-1}$ ) of the labeled detritus were estimated daily by measuring inorganic $\left[{ }^{14} \mathrm{C}_{\mathrm{CO}_{2}}\right.$ in effluent from the microcosms (Tenore et al., 1979)

After $4 \mathrm{~d}$, the microcosms were opened and $1 \mathrm{~cm}^{3}$ of surface sediment was taken by a small corer for adenylate extraction (Bancroft et al., 1976) and analysis (Tenore et al., 1979). The hot extracts were cooled in crushed ice, centrifuged, and the supernatant stored at $-20^{\circ} \mathrm{C}$. Samples that contained worms were not included in total adenylate $\left(A_{1}\right)$ estimations of microbial biomass. A Chem-Glow Photometer (American Instr. Co.) coupled to a digital integrator-timer (American Instr Co.) set for peak height analysis was used to measure the bioluminescence after injecting a firefly lantern tail extract into the sample extract.

Capitella capitata were picked from the sand, allowed to void their guts in seawater for $5 \mathrm{~h}$, quickly rinsed with $10 \% \mathrm{HCl}$ and distilled water, and dried (Tenore and Hanson, 1980). The worms were divided into groups of 4 to 5 to facilitate weighing and isotope counting. Worm tissue and detritus were combusted in a Packard sample oxidizer before liquid scintillation counting.

Rates of $\mathrm{O}_{2}$ consumption and the standing stock of microbial biomass were used to calculate specific rates

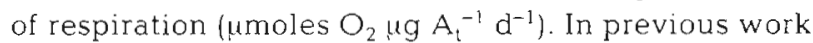
under similar conditions (Tenore, 1977), microcosms with or without Capitella capitata showed no significant changes in detrital oxidation rates $\left({ }^{14} \mathrm{CO}_{2}\right)$. Thus, C. capitata contribute little to the rates of respiration in the microcosms. Further, C. capitata biomass (numbers) was constant in all microcosms so that the observed changes reflect microbial activity due to detrital source and age.

Metabolic 'respiratory' quotient (MRQ, $\mathrm{CO}_{2} / \mathrm{O}_{2}$ ) for the detrital types of different ages were calculated from $\mathrm{O}_{2}$ consumption and $\mathrm{CO}_{2}$ production rates. The $M R Q$ describes the anaerobic to aerobic respiratory balance in the microcosm. If $\mathrm{O}_{2}$ was the sole terminal electron acceptor, then a MRQ near 0.85 would be expected (see Discussion). The magnitude of MRQ depends on (1) the nature of the oxidizing agent being reduced by microbes in oxidative and substrate phosphorylation, (2) the biochemical composition of the detritus.
Microbial deoxyribonucleic acid (DNA) synthesis was estimated by ${ }^{3} \mathrm{H}$-thymidine incorporation into DNA (Tobin and Anthony, 1978). ${ }^{3} \mathrm{H}$-thymidine $(0.04$ $\mathrm{ml}$ of $5 \mu \mathrm{Ci} \mathrm{ml} \mathrm{m}^{-1}$ solution) was added to $1 \mathrm{~cm}^{3}$ of sediment (triplicates with a formalin-killed control) from each microcosm. Samples were incubated for $2 \mathrm{~h}$ and then 'killed' with $1 \mathrm{ml}$ of $5.7 \%$ formalin. The samples were washed free of unassimilated ${ }^{3} \mathrm{H}$-thymidine and the nucleic acids solubilized overnight in $10 \mathrm{ml}$ of $0.3 \mathrm{M} \mathrm{NaOH}$. Extracts were centrifuged at $18,000 \times \mathrm{g}$ for $30 \mathrm{~min}$ and then transferred to clean tubes with $0.2 \mathrm{ml}$ of carrier DNA $(\sim 200 \mu \mathrm{g})$. The DNA was neutralized with $1 \mathrm{ml}$ of $3 \mathrm{~N} \mathrm{HCl}$ and precipitated with $1.2 \mathrm{ml}$ of $50 \% \mathrm{TCA}$. The extract was placed on ice for $30 \mathrm{~min}$, half the volume was filtered on a $0.4 \mu \mathrm{m}$ polycarbonate filter, washed twice with $4 \mathrm{ml}$ of $5 \%$ TCA, and half the volume was heated at $85^{\circ} \mathrm{C}$ for 30 min, iced for $30 \mathrm{~min}$, filtered and washed. Filters were dissolved in Soluene-350 and then counted by liquid scintillation. The difference in the counts between the 2 filters was taken as ${ }^{3} \mathrm{H}$-thymidine incorporation into DNA. Internal standards were used to correct for quench and to convert counts to $\mathrm{dpm} \mathrm{cm}^{-3} \mathrm{~h}^{-1}$.

\section{RESULTS}

\section{Temporal Changes in Microbial Activity}

\section{Microcosms}

Changes in oxygen consumption indicated that utilization of oxidizable organics by microbes varied with detrital type and age (Fig. 2A). The rates of $\mathrm{O}_{2}$ consumption correlated positively with estimates of microbial biomass (total adenylates, Fig. 3, in Tenore and Hanson, 1980). Microcosms with periphytic algal detritus had the highest initial rates of respiration indicating a rapid depletion of readily oxidizable organics during aging. Respiration rates in the microcosms with Gracilaria foliifera detritus suggest that 2 different energy pools became available or that there was a succession of decomposing organisms during aging. On the other hand, rates of respiration associated with Spartina alterniflora detritus were low during the first $100 \mathrm{~d}$ of aging and did not support high rates of respiration until after 6 months of aging.

When the rates of respiration were normalized for microbial biomass, the specific rates of respiration ( $\mu$ moles $\mathrm{O}_{2} \mu \mathrm{gA}_{1}^{-1} \mathrm{~d}^{-1}$ ) increased linearly with the age of each detrital type (Fig. 2B). We attribute the initial high rates for periphytic algal and Gracilaria folifera detritus ( $5 \mathrm{~d}$ aged) to readily-assimilable organics in the detritus. Periphytic algal detritus had the highest daily increase in specific respiration of $4 \%$, followed 

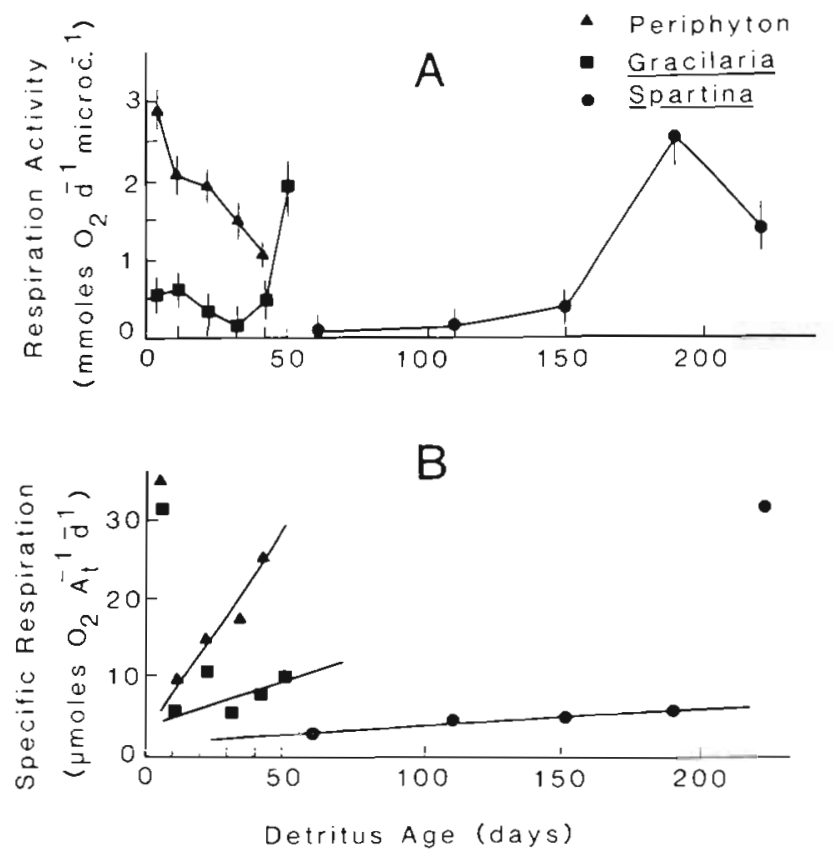

Fig. 2. Changes in respiration activity due to aging of detritus derived from different sources. Respiration rates are mean values \pm S. E., based on 8 measurements from duplicate microcosm. Respiration rates (A) were converted to specific respiration rates $(B)$ based on microbial biomass $\left(A_{t}\right)$ in each microcosm
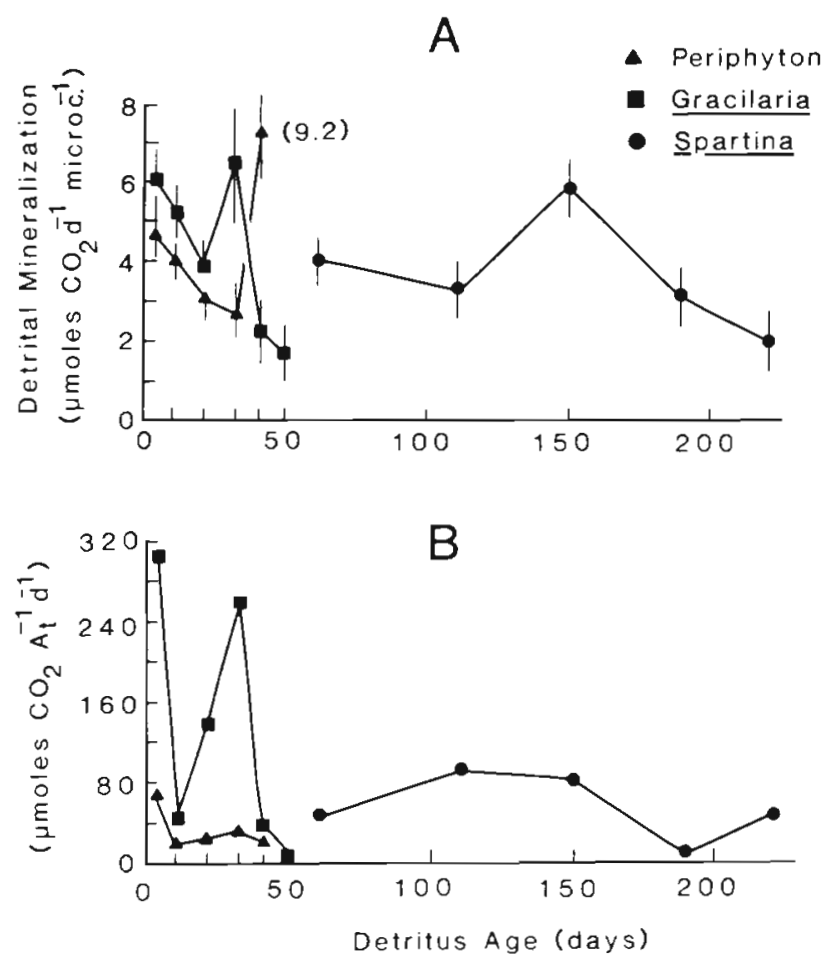

Fig. 3. Changes in mineralization due to aging of detritus derived from different sources. Same replication as in Fig. 1 Detrital mineralization (A) was converted to specific mineralization rates $(B)$ based on microbial biomass $\left(A_{t}\right)$ in each microcosm by $G$. foliifera $(1 \%)$ and Spartina alterniflora detritus $(0.3 \%)$. We attribute these differences in specific respiration of the aerobic microbes to the resistance to decay and the biochemical composition of the detritus

Gracilaria folifera and periphytic algal detritus mineralized rapidly whereas Spartina alterniflora detritus did not (Fig. 3A). In general, total $\mathrm{CO}_{2}$ production curves resembled those for detritus oxidation. determined from ${ }^{14} \mathrm{CO}_{2}$ production (Fig. 1 in Tenore and Hanson, 1980). When the rates were normalized for microbial biomass, specific rates of mineralization (Fig. 3B) generally followed the incorporation of detritus by Capitella capitella (Fig. 1 in Tenore and Hanson, 1980).

Metabolic 'respiratory' quotients (MRQ, total $\mathrm{CO}_{2}$ ' $\mathrm{O}_{2}$ ) for the detritus-microbial complex were greater than 0.85 (Fig. 4A), suggesting participation of anaerobic metabolism in the decomposition of detritus. The MRQ varied with the source of detritus and its age. During early stages of decomposition, microcosms with periphyton detritus had the lowest MRQ $(<2)$, whereas those with Gracilaria foliifera and Spartina alterniflora detritus had the highest MRQ. During later

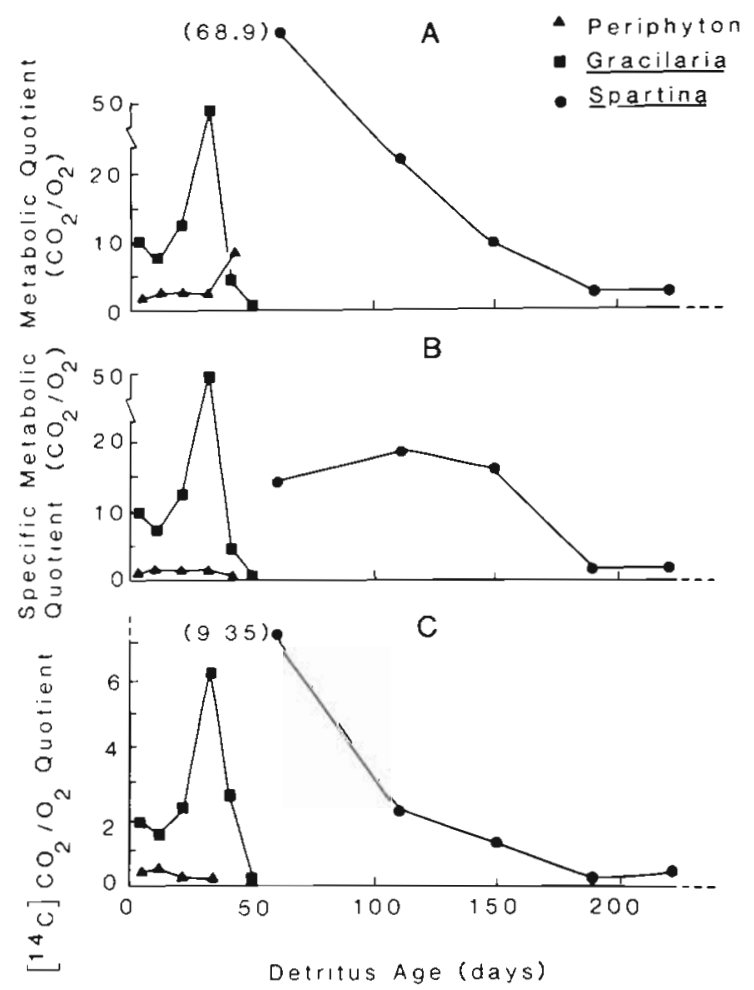

Fig. 4. Changes in metabolic quotient due to aging of detritus derived from different sources. A: metabolic quotient computed from respiration (Fig. 2A) and mineralization (Fig. 3A) rates. B: specific melabolic quotient computed from specific respiration (Fig. 2B) and mineralization (Fig. 3B) . C: detritus oxidation $\left({ }^{14} \mathrm{CO}_{2}\right)$ to respiration ratio computed from oxidation rates (reported in Tenore and Hanson, 1980) and respiration rates (Fig. 2A) 
stages of decomposition, MRQ for these latter detrital sources approached values of 2 or less. When the specific rates of respiration and mineralization were used to compute the MRQ, the specific MRQ values (Fig. 4B) were similar to the total $\mathrm{CO}_{2} / \mathrm{O}_{2}$ quotient (Fig. 4A). We also computed, for comparison, a metabolic quotient based on the rates of detritus oxidation $\left(\left[{ }^{14} \mathrm{C}_{\mathrm{CO}_{2}}\right.\right.$, Table 1 in Tenore and Hanson, 1980). The temporal changes (Fig. 4C) were similar to those in Fig. $4 \mathrm{~A}$ but the values were much lower.

\section{Aerobic Versus Anaerobic Decomposition}

\section{Culture}

Aging of Gracilaria foliifera detritus under oxic and anoxic conditions suggested that anaerobic bacteria did not assimilate the detritus as efficiently as the aerobic bacteria (Fig. 5). After 24 h, bacterial biomass

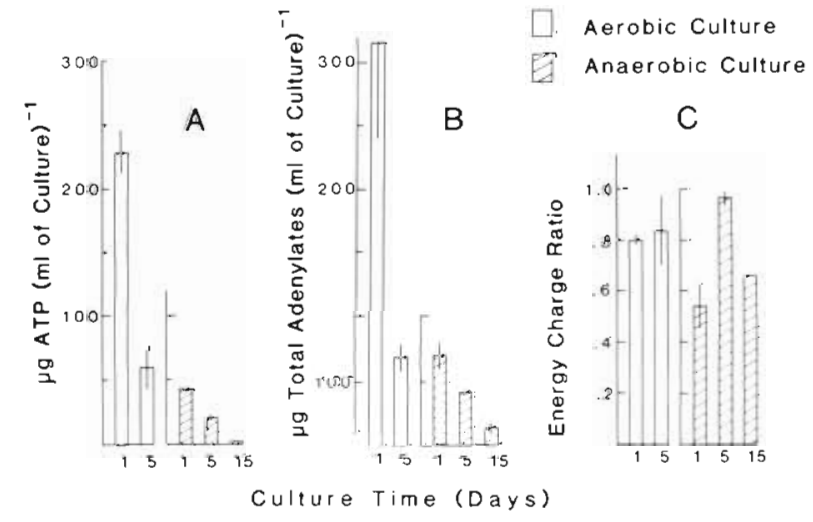

Fig. 5. Comparıson of microbial biomass (ATP and $A_{1}$ ) and physiology of the microbiota decomposing Gracilaria foliifera detritus under strictly oxic or anoxic conditions. Means \pm S. D. of 4 to 5 observations

(ATP and total adenylates, $A_{t}$ ) in aerobic culture was nearly 5 times greater than the biomass in the anaerobic culture (Fig. 5A, B). Biomass declined with aging in both cultures, and the biomass in the anaerobic culture never reached the biomass concen- trations in the aerobic culture. In addition, the detritus in the aerobic culture was almost completely mineralized after $10 \mathrm{~d}$, whereas detritus still remained in the anaerobic culture and therefore this culture was continued for another $10 \mathrm{~d}$. The adenylate energy charge (AEC) ratio of 0.8 suggests that the bacterial growth in the aerobic culture remained in exponential phase during the aging of the detritus. However, in the anaerobic culture, the $\mathrm{AEC}$ ratio was initially low $(\sim 0.55)$; it increased to the physiological state of the aerobic culture after $5 \mathrm{~d}$ of aging. This suggests that the anaerobic bacteria took longer to develop on the detritus and that anaerobic metabolism became efficient in generating energy during the latter stages of detrital decomposition even though biomass was low.

\section{Microcosms}

When equal amounts of the detritus from the cultures were placed in the microcosms and aged for an additional 4-5 d, equivalent microbial biomass (Fig. 6A and $\mathrm{B}$ ) and $\mathrm{AEC}$ ratio (Fig. 6C) were found for the $5 \mathrm{~d}$ aerobically and anaerobically aged detritus. This suggests that the microbes could efficiently utilize the detritus and end-products from anaerobic metabolism from the anaerobic culture. Because the anaerobic bacteria in the culture never attained the biomass concentration found by the aerobic bacteria, there was sufficient detritus (carbon) remaining for utilization by microbes in the microcosms. This was indicated by the high AEC ratio of $\sim 0.8$ for the microbes in the microcosms with anaerobically aged detritus (Fig. 6C).

Rates of $\mathrm{O}_{2}$ consumption in these microcosms with Gracilaria foliifera detritus aged under oxic or anoxic conditions (Fig. 7A) were not significantly different from those in microcosms with detritus aged under mixed conditions (Fig. 2A), In addition, microcosms with either the aerobically or anaerobically aged detritus showed a slight increase in $\mathrm{O}_{2}$ consumption after $10 \mathrm{~d}$ of aging. This similarity in the data suggests that reduced end-products from anaerobic metabolism was not a significant factor in the $\mathrm{O}_{2}$ consumption

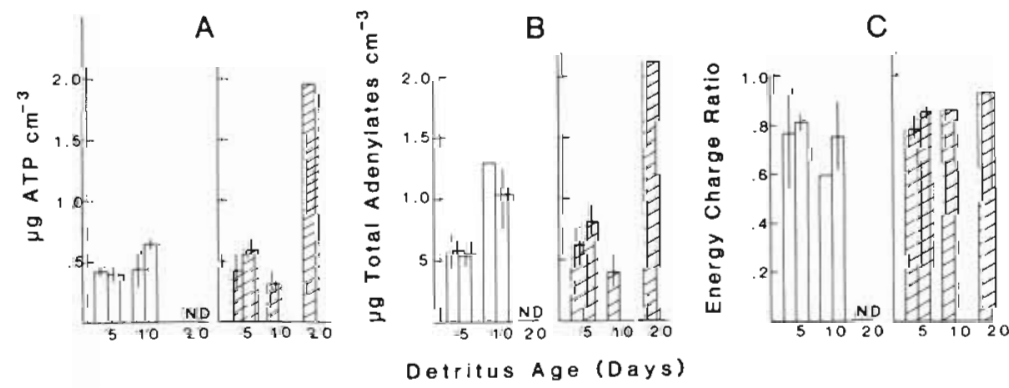

Aerobic Aged Detritus

$\triangle$ Anaerobic Aged Detritus
Fig. 6. Comparison of microbial biomass (ATP and $A_{t}$ ) and physiology (adenylate energy charge ratio) in microcosms with either aerobically or anaerobically aged Gracilaria foliiferd detritus. ND: no data 
Aerobic Aged Detritus Anaerobic Aged Detritus

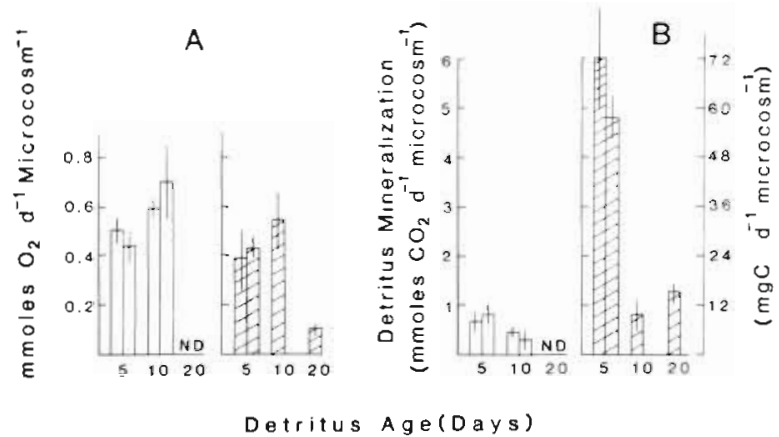

Fig. 7. Comparison of respiration (A) and detritus mineralization (B) in microcosms with either aerobically or anaerobically aged Gracilaria foliifera detritus. ND: no data

rates. However, aging the detritus anaerobically for 15 $d$ in the culture resulted in rates of respiration that were significantly reduced (Fig. $7 \mathrm{~A}$ ).

Rates of $\mathrm{CO}_{2}$ production in microcosms with anaerobically aged Gracilaria foliffera detritus (Fig. 7B) were similar to those for mixed conditions (Fig. 3A), but 2 to 6 times higher than those observed for aerobically aged detritus (Fig. 7B). Consequently, the metabolic 'respiratory' quotients for anaerobically aged detritus (Fig. 8) were similar to those for detritus

\section{$\square$ Aerobic Aged Detritus \\ Anaerobic Aged Detritus}

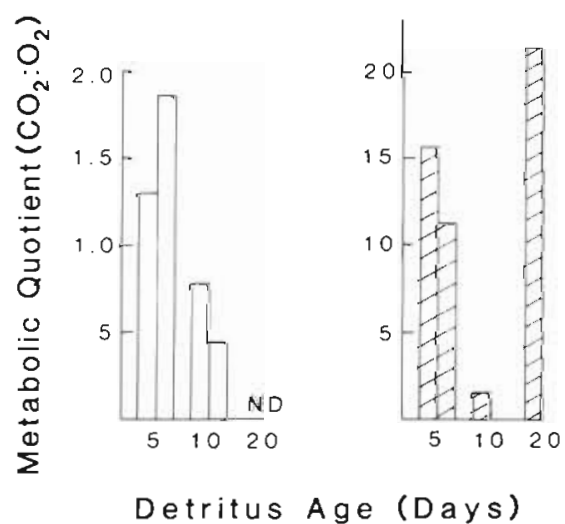

Fig. 8. Comparison of metabolic quotients in microcosms with either aerobically or anaerobically aged Gracilaria folifera detritus. ND: no data

aged under mixed conditions (Fig. 4A). These observations suggest that anaerobic bacteria originated from the aging cultures and were active in the mineralization of the detritus.

The rates of detritus oxidation $\left({ }^{14} \mathrm{CO}_{2}\right)$ and incorporation by Capitella capitata of aerobically and anaerobically aged detritus are shown in Fig. 9. In general, rates of oxidation were similar for both aerobically and anaerobically aged detritus, and the rates decreased

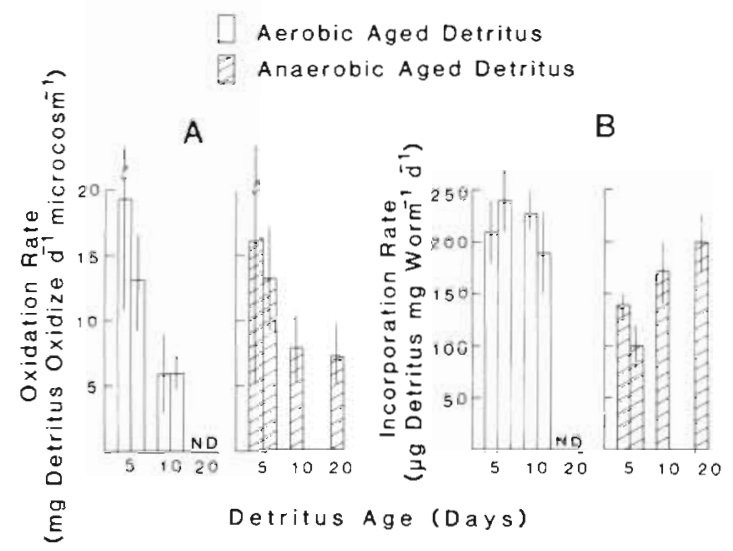

Fig. 9. Comparison of detritus oxidation (A) and net incorporation $(B)$ rates of aerobically or anaerobically aged Gracilaria foliffera detritus by Capitella capitata. Oxidation values are means $\pm S$. D. based on 15 observations. Net incorporation values are based on at least 15 observations (each 4 to 5 individual worms pooled) for each of 2 replicate microcosms. ND: no data

with aging time (Fig. 9A). C. capitata, on the other hand, incorporated the aerobically aged Gracilaria foliifera detritus at rates initially higher $(47 \%)$ than the anaerobically aged detritus (Fig. 8B). However, after $20 \mathrm{~d}$ of aging, C. capitata incorporated the anaerobically aged $G$. foliffera detritus as well as aerobically aged detritus.

Rates of thymidine incorporation into microbial DNA decreased over time for Gracilaria foliifera detritus aged aerobically whereas DNA synthesis increased over time for $G$. foliifera detritus aged anaerobically (Fig. 10). This trend resembles the rates at which Capitella capitata incorporated anaerobically aged

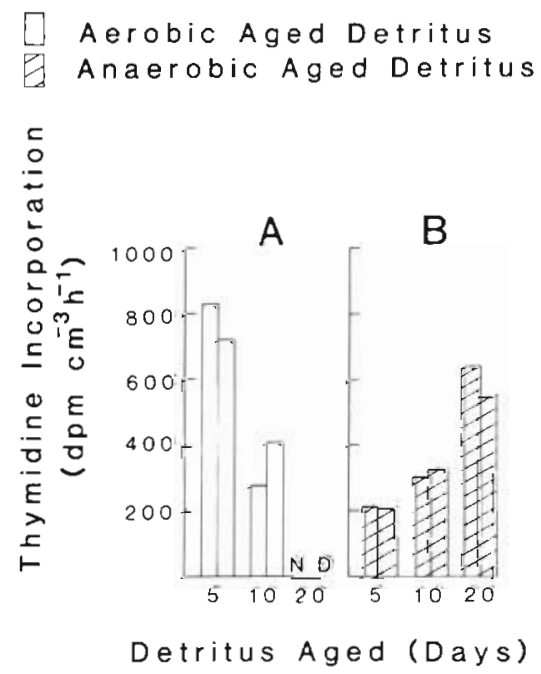

Fig. 10. Comparison of thymichne incorporation into the DNA of the microbiota in microcosms with either aerobically or anaerobically aged Grariaria folufera detritus. ND: no data 
detritus (Fig. 9B). Apparently, the anaerobically aged detritus possessed carbon pools even after $20 \mathrm{~d}$ of aging for microbial and C. capitata growth

\section{DISCUSSION}

The rates of microbial activity associated with aging detritus derived from periphytic algae, Gracilaria foliffera and Spartina alterniflora (Fig. 2A) describe (1) the relative structural complexity of biochemical composition of these detrital types, and (2) the availability of the carbon components over time to aerobic and anaerobic microbes. Because rates of respiration correlated with the concentration of microbial biomass associated with the detritus (Tenore and Hanson, 1980), fluctuations could be caused by resistance to decay and/or turnover of microbial populations. By normalizing rates of respiration to microbial biomass and perhaps metabolism can be nullified. Thus, the rates of respiration per unit of biomass (referred to as the specific rates of respiration) describe resistance to decay of each detrital type over time. Two aspects worth noting are: (1) even during the latter stages of decomposition and periods of low microbial biomass the activity of microbes was higher than during periods of high biomass in the early stages of decomposition i. e. the specific rates of respiration of the microbes increased; (2) the daily increase in the specific rate of respiration was linear over most of the aging period.

Structural cellulose and lignin content probably contributes to the relative resistance of the different detrital types to decay. In Spartina alterniflora, lignocellulose and lignin content represents 75 and $15 \%$ respectively of the ash-free dry weight (MacCubbin and Hodson, 1980). However, available caloric content of detrital sources may also influence decomposition and utilization (Tenore, 1981; Hanson, in press). Available calories in Gracilaria folifera and S. alterniflora stocks are 1.89 and $0.75 \mathrm{Kcal} \mathrm{g}^{-1}$ dry wt. or $57 \%$ and $17 \%$ of the total calories respectively (Tenore, 1981). Thus, $S$. alterniflora detritus with high lignocellulose and low available caloric content resists decomposition and conversion to microbial carbon (Haines and Hanson, 1979; Tenore et al., 1979; MacCubbin and Hodson, 1980; Hanson, 1980)

The similarity between increase in the specific rate of respiration (Fig. 2B) and in the P:Oratio, the ratio of detrital incorporation into Capitella capitata production $(P)$ to the oxidation $(O)$ of labeled detrital carbon (Fig. 2, Tenore and Hanson, 1980), suggests that either C. capitata production was coupled to microbial conversion and utilization of these detrital types or both were competing for similar nutrients in the detritus. The $\mathrm{P}: \mathrm{O}$ ratio is defined as a measure of the cost efficiency of the microcosm to produce macroconsumers (Tenore and Hanson, 1980). Daily increases in $\mathrm{P}: \mathrm{O}$ ratios were $0.3 \%, 1.2 \%$ and $2.3 \%$ for Spartina alterniflora, Gracilaria folifiera and periphytic algal detritus respectively. The daily change in the specific rate of respiration and $\mathrm{P}: \mathrm{O}$ ratio also corresponds to daily changes in $A_{t}: O$ ratios (Fig. 4 in Tenore and Hanson, 1980). Daily changes in $A_{1}: O$ ratios in microcosms with Spartina alterniflora, Gracilaria foliifera and periphytic algal detritus were $0.8 \%, 4.3 \%$ and $8.4 \%$ respectively, suggesting that microbial activity is important in the decomposition of the detritus and in production of the polychaete Capitella capitata.

The rates of mineralization $\left(\mathrm{CO}_{2}\right)$ of the 3 types of detritus did not correlate exactly with the rates of detritus oxidation $\left(\left[{ }^{14} \mathrm{C}\right] \mathrm{CO}_{2}\right.$; Tenore and Hanson, 1980). Possible causes are: (1) there was an external carbon source (DOC) in the $1 \mu \mathrm{m}$-filtered, estuarine water flushing the microcosm; (2) detritus was not uniformally labeled. We estimated that less than 1 to $10 \%$ of the mineralization rates was due to DOC. However, DOC may be a significant carbon source to microorganisms when structural components of the detritus resist decay. We felt that the detrital carbon was uniformally labeled because of the similarity in the $\mathrm{CO}_{2} / \mathrm{O}_{2}$ and ${ }^{14} \mathrm{CO}_{2} / \mathrm{O}_{2}$ quotients over time, and because specific rates of mineralization resembled temporal changes in $A_{L}: O$ ratios (Fig. 4 in Tenore and Hanson, 1980).

Anaerobic bacteria contributed mostly to the $\mathrm{CO}_{2}$ produced in the microcosms. Respiratory quotients (RQ) of eukaryotes and aerobic procaryotes utilizing carbohydrates at steady-state are about 0.7 to 0.85 (Payne, 1970; Boyd, 1973). However, the quotient is greatly affected by anaerobic metabolism. In mixed aerobic and anaerobic communities the metabolic 'respiratory' quotient (not synonomous with $R Q$ ) is usually greater than 0.85 (Rich, 1979). Therefore, the magnitude of the $M R Q$ indicates a balance between aerobic respiration $\left(\mathrm{O}_{2}\right)$ and the respiratory demand on other terminal electron acceptors $\left(\mathrm{NO}_{3}^{-}, \mathrm{SO}_{4}^{-}, \mathrm{CO}_{2}\right.$ and oxidizable organics). The high MRQ for these detrital types in our microcosms are similar to the MRQ for many shallow marine and freshwater benthic systems (Park et al., 1958; Odum et al., 1963; Wood and Verduin, 1972; Rich, 1975, 1979; Hanson et al., 1981).

Because of high metabolic 'respiratory' quotients in well-aerated microcosms, we suspected that anaerobic bacteria survived pretreatment, e. g. freeze-drying and rehydration, and low oxygen or anoxic condition existed in localized niches within detrital aggregates. We examined this possibility with Gracilaria foliifera detritus aged under oxic and anoxic conditions. The results indicate that anaerobic aging of the detritus increased the magnitude of the metabolic quotients. 
Therefore, we attributed the high quotients to metabolism by anaerobes associated with the detritus.

Even though 3 detrital types were decomposed under mixed aerobic and anaerobic processes, Capitella capitata incorporated the anaerobically aged Gracilaria foliifera detritus at the same magnitude as aerobically aged detritus. Oxic or anoxic aging made little difference in the suitability of the detritus to $C$. capitata. However, $G$. folifera detritus from anaerobic cultures did require a longer period of aging before incorporation rates of anaerobically aged detritus by $C$. capitata approached those of the aerobically aged detritus. The results suggest that the aerobic culture had the highest conversion efficiency of the detritus to microbial carbon. Contrarily, the anaerobic culture had the lowest efficiency based on the low biomass and $A E C$ ratio but became active after several days of aging.

Because of the low conversion and decomposition of Gracilaria foliifera detritus under anoxic conditions this detritus retained sufficient carbon reserve for further microbial metabolism and Capitella capitata production. For example, in microcosms with anaerobically aged detritus, microbial DNA synthesis increased with time and coincided with the increase in incorporation by C. capitata. On the other hand, microbial DNA synthesis decreased with time in the microcosms with aerobically aged detritus and $C$. capitata incorporation rates remained unchanged. In these microcosms, microbial biomass remained sufficiently high to support C. capitata activities. In addition, changes in DNA synthesis in microcosms with aerobic and anaerobic aged detritus followed the AEC ratio which is a relative measure of microbial growth rate (Wiebe and Bancroft, 1975). Therefore, if microbial biomass is high, C. capitata production is not tightly coupled to microbial production. Contrarily, if microbial biomass is low, $C$. capitata production is tightly coupled to microbial production.

Our results confirm the resistance of Spartina alterniflora detritus to decay and that the transfer of decayresistant detritus to secondary consumers is mediated by microbes (Tenore and Hanson, 1980). Further, we show that anaerobic metabolism limits the flow of particulate carbon in the detrital food web. The carbon shunt results from the loss of $\mathrm{CO}_{2}$ carbon during anaerobic metabolism and conversion of detritus to microbial carbon. Therefore, if the $\mathrm{CO}_{2}$ escapes fixation by benthic chemoautotrophs, then $\mathrm{CO}_{2}$ ebullition from the sediments would represent a significant loss of carbon from the food web.

\section{LITERATURE CITED}

Bancroft, K, Paul, E. A., Wiebe, W. J. (1976). The extraction and measurement of adenosine triphosphate from marine sediments. Limnol. Oceanogr 21: 473-480

Boyd, C. E. (1973). The chemical oxygen demand of waters and biological material from ponds. Trans. Am Fish. Soc. 102: 606-611

Burkholder, P. R., Bornside, G. H., (1957). Decomposition of marsh grass by aerobic marine bacteria. Bull. Torrey Botanical Club 84: 366-383

Fallon, R. D., Pfaender, F. K. (1976). Carbon metabolism in model microbial systems from a temperature salt marsh. Appl. environ. Microbiol. 3: 959-968

Fenchel, $T$ (1972). Aspects of decomposer food chains in marine benthos. Verh. dt. zool. Ges. 65: 14-22

Fenchel, T M. (1978). The ecology of micro- and meiobenthos. Ann. Rev. Ecol. Syst. 9: 99-121

Gosselink, J. G., Kirby, C. J. (1974). Decomposition of salt marsh grass, Spartina alterniflora Loisel. Limnol. Oceanogr 19: 825-832

Gunnison, D., Alexander, M. (1975). Basis for the resistance of several algae to microbial decomposition. Appl. Microbiol. 29: 729-738

Hackney, C. T., de la Cruz, A. A. (1980). In situ decomposition of roots and rhizosomes of two tidal marsh plants. Ecology 61: 226-231

Haines, E. B., Hanson, R. B. (1979). Experimental degradation of detritus made from the salt marsh plants, Spartina alterniflora Loisel., Salicornia virginica L., and Juncus roemerianus Scheele. J. exp. mar. Biol. Ecol. 40: 27-40

Hanson, R. B. (1980). Measuring microbial activity to assess detrital decay and utilization. In: Tenore, K. R., Coull, B. C. (eds.) Marine benthic dynamics. University of South Carolina Press, Columbia, S. C., pp. 345-354

Hanson, R. B. (In press). Organic nitrogen and caloric content II. Microbial biomass and activity. Estuar. coast. Shelf Sci.

Hanson, R. B., Tenore, K. R., Bishop, S., Chamberlain, C. F. Pamatmat, M. M., Tietjen, J. H. (1981). Benthic enrichment in the Georgia Bight related to Gulf stream intrusions and estuarine outwelling. J. mar. Res. 39: 417-441

Harrison, P. G., Mann, K. H. (1975). Detritus formation from eelgrass, (Zostera marina L.): The relative effects of fragmentation, leaching and decay. Limnol. Oceanogr 20 924-934

Josselyn, M. N., Mathieson, A. C. (1980). Seasonal influx and decomposition of autochthonous macrophyte litter in north temperature estuary. Hydrobiologia 71. 197-208

MacCubbin, A. E., Hodson, R. E. (1980). Mineralization of detrial lignocelluloses by salt marsh sediment macroflora. Appl. environ. Microbiol. 40: 735-740

Odum, E. P., de la Cruz, A. A. (1967). Particulate organic detritus in Georgia salt marsh-estuarine ecosystem. In Lauff, G. H. (ed.) Estuaries. Publs Am. Ass. Advmt Sci. 83 383-388

Odum, H. T., Cuzon du Rest, R. P., Beyers, R. J., Allbaugh, C. (1963). Diurnal metabolism, total phosphorous, Ohle anomaly, and zooplankton diversity of abnormal marine ecosytems of Texas. Publs Inst. mar Sci. Univ. Tex. 9: $404-4.54$

Park, K., Wood, D. W. Odum, H. T (1958). Diurnal pH variation in Texas bays and its application to primary production estimation. Publs Inst. mar. Scı. Univ. Tex. 5: $47-64$

Payne, W. J. (1970), Energy yield and growth of heterotrophs. Ann. Rev. Microbiol. 24: 17-52 
Rich, P. H. (1975). Benthic metabolism of a soft-water lake Verh. int. Verein. theor. angew. Limnol. 19: 1023-1028

Rich, P. H. (1979). Differential $\mathrm{CO}_{2}$ and $\mathrm{O}_{2}$ benthic community metabolism in a soft-water lake. J. Fish. Res. Bd Can. 36: $1377-1389$

Teal, J. M. (1962). Energy flow in the salt marsh ecosystem of Georgia. Ecology 43: 614-624

Tenore, K. R. (1976). Food chain pathways in detrital feeding benthic communities: A review, with new observations on sediment resuspension and detrital cycling. In: Coull, B. C. (ed.) Ecology of marine benthos. Belle W Baruch Library in Marine Science, University of South Carolina Press, Columbia, pp. 37-54

Tenore, K. R. (1977). Utilization of aged detritus derived from different sources by the polychaete Capitella capitata. Mar. Biol. 44: 51-55

Tenore, K. R. (1981). Organic nitrogen and caloric content of detritus. I. Utilization by the deposit-feeding polychaete Capitella capitata. Estuar. coast. Shelf Sci. 12: 39-47

Tenore, K. R., Hanson, P. B. (1980). Availability of detritus of different types and ages to a polychaete macroconsumer, Capitella capitate. Limnol. Oceanogr. 25: 553-558

Tenore, K. R., Hanson, R. B., Dornseif, B., Wiederhold, G.
(1979). The effect of organic nitrogen supplement on the utilization of different sources of detritus. Limnol. Oceanogr. 24: 350-355

Tenore, K. R., Rice, D. (1980). A review of trophic factors affecting secondary production of deposit feeders. In: Tenore, K. R., Coull, B. C. (eds.) Marine benthic dynamics. University of South Carolina Press, Columbia, pp. 325-340

Tobin, R. S., Anthony, D. H. J. (1978). Tritiated thymidine incorporation as a measure of microbial activity in lake sediments. Limnol. Ocenogr 23: 161-165

Valiela, I., Koumjian, L., Swain, T., Teal, J. M., Hobbie, J. E. (1979). Cinnamic acid inhibition of detritus feeding. Nature, Lond. 280: 55-57

White, D. A., Weiss, T E.,rapani, J. M.,hien, L. B. (1978). Productivity and decomposition of the dominant salt marsh plants in Louisiana. Ecology 58: 751-759

Wiebe, W. J., Bancroft, K. (1975). Use of the adenylate energy charge ratio to measure growth rates of natural microbial communities. Proc. natn. Acad. Sci. U.S.A. 72: 2112-2115

Wood, K. G., Verduin, J. (1972). Correlation between $\mathrm{CO}_{2}$ and $\mathrm{O}_{2}$ concentrations in Lake Erie, USA. Arch. Hydrobiol. 71 $1-16$ 